\title{
Electrospray tandem mass spectrometry of ecdysteroid moulting hormones
}

\author{
Jocelyne Hellou, Joseph Banoub*, Emmanuel Gentil, \\ Dave M. Taylor and Paul G. O'Keefe \\ Department of Fisheries \& Oceans, Northwest Atlantic Fisheries Center, Science Branch, \\ Toxicology Section P.O. Box 5667, St John's Newfoundland, A1C 5X1, Canada
}

\begin{abstract}
Electrospray mass spectrometry has aided the structural characterization of ecdysteroid moulting hormones as a means of understanding factors controlling the moulting cycle in crabs. Possible fragmentation routes were first obtained by controlled collision-activated dissociation (CAD) initiated by cone voltage fragmentation. Low energy CAD MS/MS analyses of the protonated molecules $[\mathrm{M}+\mathrm{H}]^{+}$confirmed the characteristic fingerprint patterns obtained by cone voltage fragmentation. MS/MS analyses of selected intermediate fragments provided additional structural data and established the fragmentation routes.
\end{abstract}

\section{Introduction}

Over one hundred different steroids, with varying degrees of hydroxylation, containing the basic $5 \beta, 7-e n-6$-one moiety of ecdysone have been isolated from plants, insects and crustaceans. Ecdysteroids in invertebrates have been related to the animals' life cycle and especially moulting [1]. Research has generally pointed to the Y organs from crustaceans and the prothoracic gland from insects as the primary secretory glands. However, auxiliary sources of ecdysteroids, in both animal groups, have also been proposed [2].

Insects and crustaceans do not biosynthesize ecdysteroids de novo, but biotransform dietary cholesterol or C-24 alkylsterols into ecdysone derivatives [3,4]. As well, a wider variety of ecdysteroids have been found in the blood of crustaceans than in most insects. In plants, there are indications that ecdysteroids play a role in defence against insects, but their function is not as well defined as in animals.

The earlier structural work reported in the literature was carried out on compounds isolated from plant sources. Larger quantities of material facilitated the full spectroscopic characterization and chemical degradation needed for the unambiguous identification of the molecules. Later, advances in chromatography, immunoassays and spectroscopy enabled full or partial characterization of ecdysteroids in a variety of species where $\alpha$-ecdysone $\mathbf{1}$ and $\beta$-ecdysone 2 are major components (Figure 1).

The present study was originally initiated to elucidate the structure of the moulting hormones of snow crabs as a means of understanding the moulting cycle in crabs. The knowledge of the identity of the moulting hormones might, perhaps, enable us to determine what factors, particularly environmental, might interfere with the efficacy of moulting 
hormones and cause massive moult failures within snow crab populations. Such a phenomenum was observed off the Avalon Peninsula in the early 1980's with devastating consequences to the snow crab industry.

Mass spectrometry is the technique of choice for structural elucidation studies of these ecdysteroids. GC-MS and LC-MS have been used with strong and mild ionization techniques. Because ecdysteroids are polar molecules, they need derivatization prior to volatilization for GC related analyses. Due to the lack of reactivity of the hindered hydroxy positions, this necessity has led to the development of alternate MS approaches [5].

While electron impact (EI) was the only available MS technique in the late sixties and early seventies, a plethora of different MS techniques, covering a wide range of ionization modes, emerged during the last decade. A short summary of MS techniques used in the literature to investigate the structure of ecdysteroids is presented in Table 1. More information on techniques used in the analysis of ecdysteroids and MS techniques in general, can be found in recent reviews $[13,14]$.

Electrospray ionization is well established as a robust LC-MS technique that allows rapid, accurate and sensitive analysis of a wide range of analytes from low molecular weight polar compounds (less than 200Da) to biopolymers larger than $100 \mathrm{KDa}$. Although ESMS has been distinguished for its ability to produce intact multiple-charged ions from proteins and other biopolymers $[15,16]$, compounds of less than $1 \mathrm{KDa}$ produce singlecharged molecules. Under appropriate experimental conditions, gas-phase fragmentations are minimized and the subsequent ions, which possess low internal energy, are sufficiently stable to pass from the ion source to the detector without dissociation. This is common for ions produced under "very soft" ionization processes.

Dissociations may be induced or activated by collision. In this process, a portion of the kinetic energy of the ion is converted to internal energy by colliding with a neutral gas phase species, usually in the pressurized collision cell of tandem MS/MS instruments $[17,18]$. Ions that have undergone this collisional excitation process may subsequently fragment. Thus, collision-activated dissociation CAD MS/MS, also known as low-energy $\mathrm{CAD} \mathrm{MS} / \mathrm{MS}$, is a valuable method for generating structural information if the primary ionization process does not impart enough internal energy for spontaneous fragmentation to occur [19].

Another method of generating structural information, known as cone voltage fragmentation, is by dissociation of the protonated molecular ion $[\mathrm{M}+\mathrm{H}]^{+}$by controlled adjustment of the accelerating voltage $(0 \pm 250 \mathrm{~V})$ applied to the sampling cone or focus voltage of the electrospray source. This procedure is also known as $\mathrm{CAD}$ in the atmospheric pressure/vacuum interface region, under mild conditions [20]. Unlike CAD experiments performed using tandem mass spectrometers, no mass filtering precedes ion-neutral collisions. Mass analysis of surviving precursor ions, plus the decomposition products generated by the subtotal of all dissociations, from all precursors, contribute to the ions observed in the CAD spectrum.

In the following paper we present the electrospray mass spectrometry (ESMS) analysis of 2,3,14,22,25-pentahydroxycholest-7-en-6-one ( $\alpha$-ecdysone) 1 and 2,3,14,20,22,25 -hexahydroxy-cholest-7-en-6-one ( $\beta$-ecdysone) 2 (Figure 1).

The present study relates to the structural characterization and differentiation of $\alpha$ ecdysone and $\beta$-ecdysone using electrospray MS in the positive and negative ion modes. Evidence of the possible fragmentation routes was first obtained by cone voltage fragmentation. Structural information was also derived from low energy tandem mass spectral analysis (MS/MS) of the protonated molecules $[\mathrm{M}+\mathrm{H}]^{+}$. Rationalization of the fragmentation routes was made by obtaining the product and precursor ion spectra of the various intermediate ions. 
<smiles>[R]C(C)([C@@H](O)CCC(C)(C)O)[C@H]1CC[C@]2(O)C3=CC(=O)[C@@H]4C[C@H](O)[C@@H](O)C[C@]4(C)[C@H]3CC[C@]12C</smiles>

$$
\begin{array}{ll}
1 & \alpha \text {-ecdysone } \mathrm{R}=\mathrm{H} \\
2 & \beta \text {-ecdysone } \mathrm{R}=\mathrm{OH}
\end{array}
$$

Figure 1. Chemical structures of ecdysteroids $\alpha$-ecdysone 1 and $\beta$-ecdysone 2.

Table 1

Examples of the analysis of ecdysteroids using various mass spectroscopy techniques

$\begin{array}{lll}\begin{array}{l}\text { Chromatography } \\ \text { and ionization }\end{array} & \text { Ecdysteroid derivative } & \text { Reference } \\ \text { GC-EI } & \text { trimethylsilyl } & \text { Ikekawa } \text { et al [6] } \\ \text { GC-EI } & \text { carboxymethoxyamine } & \text { Borst and O'Connor [7] } \\ \text { FAB }^{+} & \begin{array}{l}\text { metabolites } \\ \text { (fatty acids) }\end{array} & \text { Dinan [8] } \\ \text { FAB }^{-} & \text {free } & \text { Wilson } \text { et al [9] } \\ \mathrm{DCI}^{-} & \text {free } & \text { Lachaise } \text { et al [10] } \\ \text { EI (direct introduction) } & \text { free } & \text { Rudolph } \text { et al [11] } \\ \text { TS } & \begin{array}{l}\text { free and } \\ \text { acetonide }\end{array} & \text { Marco et al [12] }\end{array}$

Legend: EI: electron impact, CI: chemical ionization, DCI: desorption chemical ionization, FAB: fast atom bombardment, TS: thermospray 


\section{Results and Discussion}

The electrospray mass spectrum (positive ion mode) of $\alpha$-ecdysone 1 was recorded with a low focus voltage (30Volts) and gave the protonated molecular ion $[\mathrm{M}+\mathrm{H}]^{+}$at $\mathrm{m} / \mathrm{z}$ 465 , in addition to the adducts $\left[\mathrm{M}+\mathrm{NH}_{4}\right]^{+}$and $[\mathrm{M}+\mathrm{H}+\mathrm{MeOH}]^{+}$at $\mathrm{m} / \mathrm{z} 482$ and 497 , respectively (Figure 2a). However, since this simple ESMS lacked substantial structural information, a higher focus voltage was employed to induce fragmentation of the protonated $[\mathrm{M}+\mathrm{H}]^{+}$molecule. Such a technique can provide structurally useful information. Thus, the ESMS of $\alpha$-ecdysone 1 were recorded with focus voltages of 50 and 75 volts as shown in Figures $2 \mathrm{~b}$ and $2 \mathrm{c}$. When higher focus voltages were used, the adduct with sodium $[\mathrm{M}+\mathrm{Na}]^{+}$ at $\mathrm{m} / \mathrm{z} 487$ was observed in all the ESMS. The fragmentation route of the protonated molecular ion of this steroid was rationalized to occur by simple losses of either one, two or three molecules of water, to afford the $\left[\mathrm{M}+\mathrm{H}_{-}-\mathrm{H}_{2} \mathrm{O}\right]^{+},\left[\mathrm{M}+\mathrm{H}-2 \mathrm{H}_{2} \mathrm{O}\right]^{+}$and $\left[\mathrm{M}+\mathrm{H}-3 \mathrm{H}_{2} \mathrm{O}\right]^{+}$ fragment ions at $\mathrm{m} / \mathrm{z} 447,429$ and 411 , respectively. The elimination of two or three molecules of water can occur by a concerted single step or, more likely, by a multistep process involving the loss of molecules of water from the $\left[\mathrm{M}+\mathrm{H}-\mathrm{H}_{2} \mathrm{O}\right]^{+}$or $[\mathrm{M}+\mathrm{H}$ $\left.2 \mathrm{H}_{2} \mathrm{O}\right]^{+}$fragment ions.

Low energy tandem MS analyses were conducted to rationalize the fragmentation pathways leading to the various fragmentations obtained in the conventional ESMS. The product ion spectrum, also called daughter ion spectrum, arising from the fragmentation in the RF only hexapole collision cell of the quadrupole-hexapole-quadrupole instrument was obtained. The $[\mathrm{M}+\mathrm{H}]^{+}$ion at $\mathrm{m} / \mathrm{z} 465$ was selected for the recording of the unimolecular mass-analyzed ion kinetic energy (MIKE) and collisional activated dissociation (CAD) $\mathrm{MS} / \mathrm{MS}$. One of the main advantages of the MS/MS technique is that the origin of fragment ions can be ascertained. The $\mathrm{CAD} \mathrm{MS} / \mathrm{MS}$ of the $[\mathrm{M}+\mathrm{H}]^{+}$ion of $\alpha$-ecdysone 1 suggested the formation of the following product ions at $\mathrm{m} / \mathrm{z} 447,429,411,331,109$ and 98 (Figure $3 \mathrm{a})$. Second generation product ions of the intermediate fragment ions $\left[\mathrm{M}+\mathrm{H}-\mathrm{H}_{2} \mathrm{O}\right]^{+}$at $\mathrm{m} / \mathrm{z} 447$ were generated in an MS/MS experiment and afforded the product ions at $\mathrm{m} / \mathrm{z} 429$, 411, 331, 109 and 98, as shown in Figure 3b. Third generation product ions of the intermediate fragment ion $\left[\mathrm{M}+\mathrm{H}-2 \mathrm{H}_{2} \mathrm{O}\right]^{+}$at $\mathrm{m} / \mathrm{z} 429$, were generated in a different MS/MS experiment and afforded the product ions at $\mathrm{m} / \mathrm{z} 411,331,109$ and 98 (Figure 3c).

The proposed fragmentation route of the protonated molecule $[\mathrm{M}+\mathrm{H}]^{+}$of ecdysone, as determined by ESMS and CAD MS/MS, is shown in Figure 4. The product ion at $\mathrm{m} / \mathrm{z}$ 331 has been tentatively assigned as originating either from the $\left[\mathrm{M}+\mathrm{H}-\mathrm{H}_{2} \mathrm{O}\right]^{+}$fragment ion at $\mathrm{m} / \mathrm{z} 447$ by the loss of the $\mathrm{HO}-\mathrm{CH}=\mathrm{CH}_{-}-\mathrm{CH}_{2}-\mathrm{C}(\mathrm{Me})_{2} \mathrm{OH}(116$ a.m.u. ) side chain or from the $\left[\mathrm{M}+\mathrm{H}-2 \mathrm{H}_{2} \mathrm{O}\right]^{+}$fragment ion at $\mathrm{m} / \mathrm{z} 429$ by the loss of the $\mathrm{HO}-\mathrm{CH}=\mathrm{CH}-\mathrm{CH}=\mathrm{C}(\mathrm{Me})_{2}(98$ a.m.u.) side chain. The product ions at $\mathrm{m} / \mathrm{z} 109$ and 98 are produced, from the side chain, by elimination and were attributed to $\left[\mathrm{CH}_{2}=\mathrm{CH}-\mathrm{CH}=\mathrm{CH}-\mathrm{CH}=\mathrm{C}(\mathrm{Me})_{2}+\mathrm{H}\right]^{+}$and $[\mathrm{HO}-$ $\left.\mathrm{CH}=\mathrm{CH}-\mathrm{CH}=\mathrm{C}(\mathrm{Me})_{2}+\mathrm{H}\right]^{+}$, respectively.

Schematic representation of the applicable scan mode is conveniently represented on all the MS/MS figures with symbols (filled circle indicates a fixed or preselected mass, open circle indicates a scanned or variable mass), as described by Wysocki [19] and originally introduced by Cooks and co-workers [21].

In a different set of experiments, the precursors of the $\left[\mathrm{M}+\mathrm{H}-2 \mathrm{H}_{2} \mathrm{O}\right]^{+}$fragment ion at $\mathrm{m} / \mathrm{z} 427$ were sought using the precursor ion scan technique (parent ion scan). It was established that this ion originated from either the intermediate ion $\left[\mathrm{M}+\mathrm{H}-\mathrm{H}_{2} \mathrm{O}\right]^{+}$at $\mathrm{m} / \mathrm{z} 447$ or the protonated molecule $[\mathrm{M}+\mathrm{H}]^{+}$at $\mathrm{m} / \mathrm{z} 465$ (Figure 5). Similarly, it was established that the $\left[\mathrm{M}+\mathrm{H}-\mathrm{H}_{2} \mathrm{O}-\mathrm{HO}-\mathrm{CH}=\mathrm{CH}-\mathrm{CH}_{2}-\mathrm{C}(\mathrm{Me})_{2} \mathrm{OH}\right]^{+}$ion at $\mathrm{m} / \mathrm{z} 331$, originated from either the intermediate fragment ion $\left[\mathrm{M}+\mathrm{H}-\mathrm{H}_{2} \mathrm{O}\right]^{+}$at $\mathrm{m} / \mathrm{z} 447$, by loss of the 116 a.m.u. side chain, or the protonated molecule $[\mathrm{M}+\mathrm{H}]^{+}$at $\mathrm{m} / \mathrm{z} 465$, by the concerted loss of a molecule of water and the 116 a.m.u. side chain (Figure 6). 


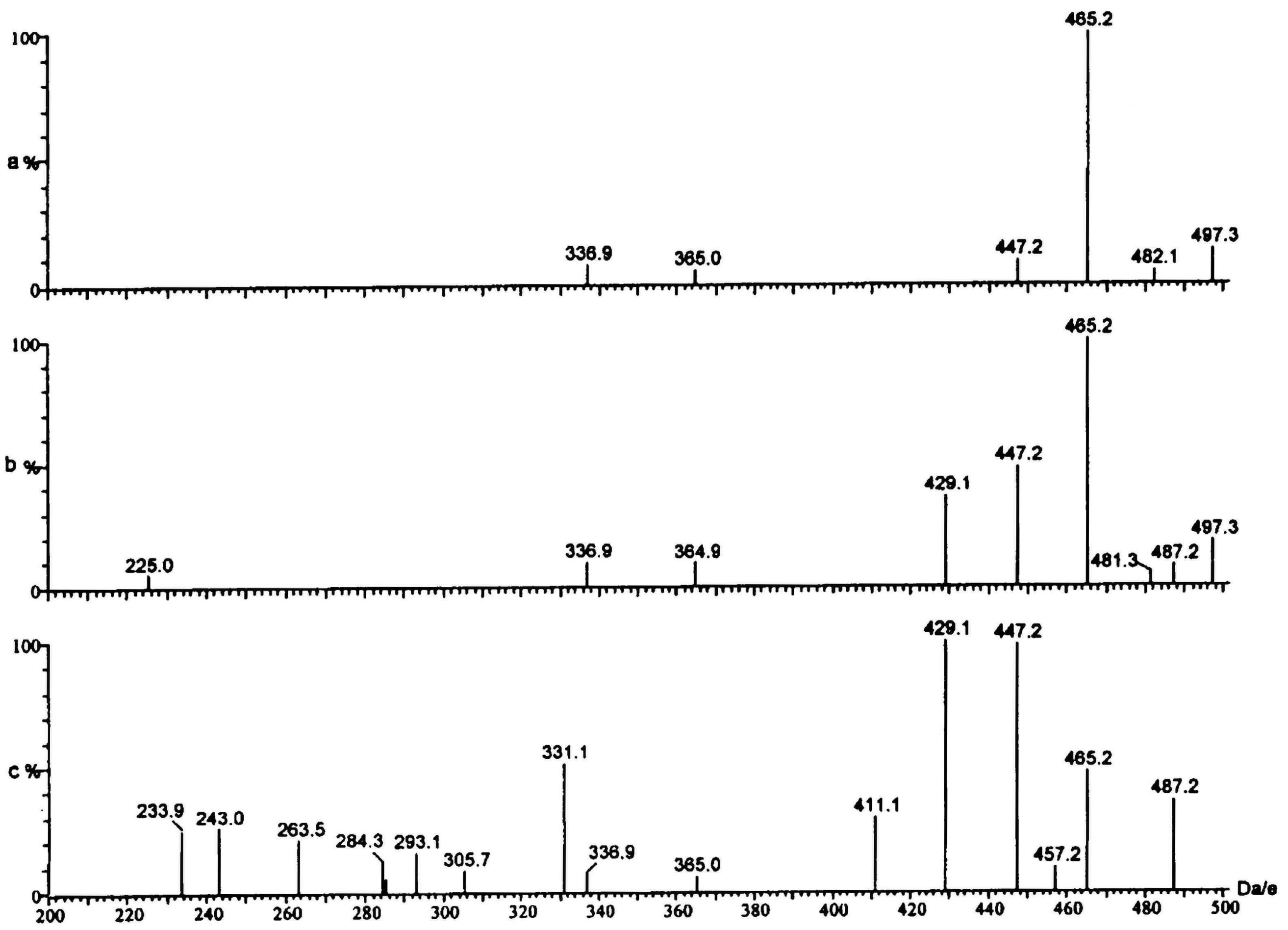

Figure 2. Electrospray mass spectra of $\alpha$-ecdysone 1 recorded with focus voltages of (a) 30 Volts, (b) 50 Volts and (c) 75 Volts. Figure 3. Low energy CAD MS/MS of (a) the molecular ion $[\mathrm{M}+\mathrm{H}]^{+}$of $\alpha$-ecdysone 1 at $\mathrm{m} / \mathrm{z} 465$, (b) the fragment ion $\left[\mathrm{M}+\mathrm{H}_{-} \mathrm{H}_{2} \mathrm{O}\right]^{+}$at $\mathrm{m} / \mathrm{z} 447$ and (c) the fragment ion $\left[\mathrm{M}+\mathrm{H}-2 \mathrm{H}_{2} \mathrm{O}\right]^{+}$at $\mathrm{m} / \mathrm{z} 427$.

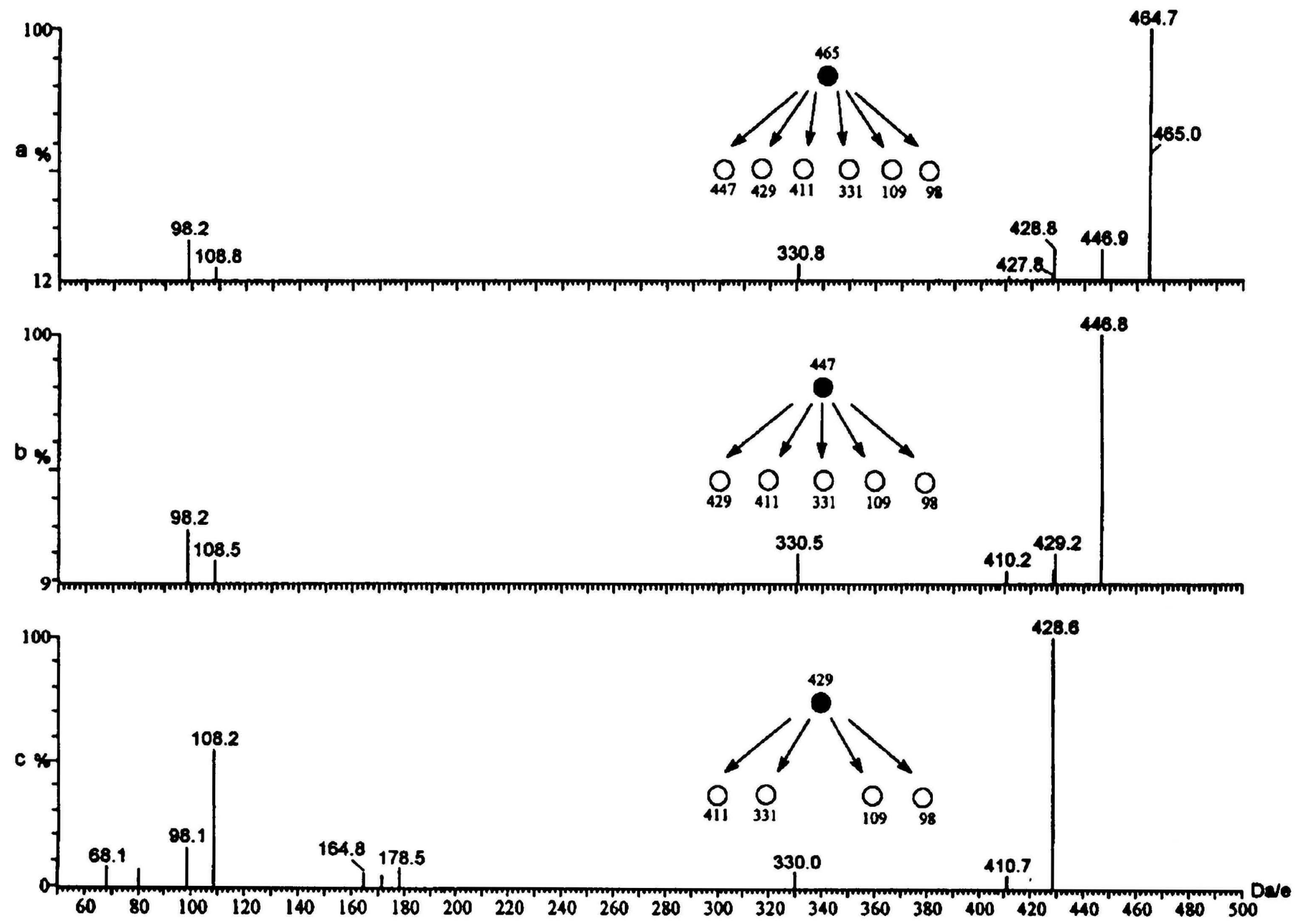


<smiles>C[C@H](C(O)CCC(C)(C)O)C1CCC2(O)C3=CC(=O)C4CC(O)C(O)CC4(C)C3CCC12C</smiles>

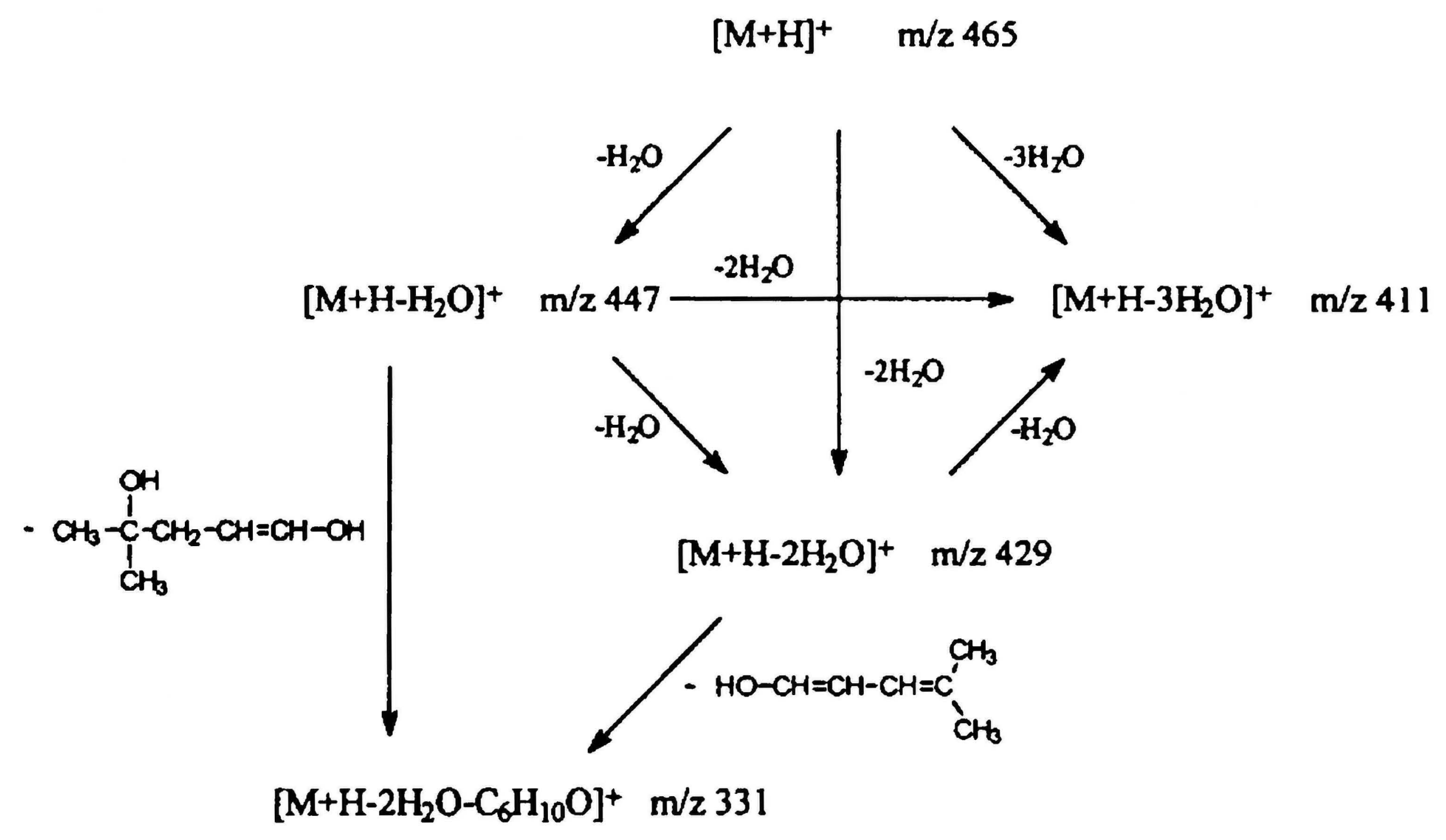

Figure 4. Major fragmentation routes of the $[\mathrm{M}+\mathrm{H}]^{+}$ion of $\alpha$-ecdysone 1 observed by ESMS and $\mathrm{CAD} \mathrm{MS} / \mathrm{MS}$.

The ESMS of $\alpha$-ecdysone 1 , in the negative ion mode, afforded a major peak at $\mathrm{m} / \mathrm{z}$ 499 , assigned to $\left[\mathrm{M}-\mathrm{H}+2 \mathrm{H}_{2} \mathrm{O}\right]$;, resulting from the deprotonated molecular ion adduct with two molecules of water.

The ESMS of $\beta$-ecdysone 2 , in the positive ion mode, was recorded with a focus voltage of 30 Volts and showed the protonated molecule $[\mathrm{M}+\mathrm{H}]^{+}$at $\mathrm{m} / \mathrm{z} 481$ in addition to the adduct $[\mathrm{M}+\mathrm{H}+\mathrm{MeOH}]^{+}$at $\mathrm{m} / \mathrm{z} 513$ (Figure 7a). However, as this mass spectrum did not provide any substantial structural information, ESMS were recorded with higher focus voltages to induce fragmentation of the molecular ion $[\mathrm{M}+\mathrm{H}]^{+}$. The ESMS of $\beta$-ecdysone 2, recorded with focus voltages of 50 and 75 Volts, are shown in Figure $7 \mathrm{~b}$ and $7 \mathrm{c}$ respectively. In these conditions, fragment ions originating from the loss of one, two or three molecules of water were observed. These fragment ions were assigned as $[\mathrm{M}+\mathrm{H}-$ $\left.\mathrm{H}_{2} \mathrm{O}\right]^{+},\left[\mathrm{M}+\mathrm{H}-2 \mathrm{H}_{2} \mathrm{O}\right]^{+}$and $\left[\mathrm{M}+\mathrm{H}-3 \mathrm{H}_{2} \mathrm{O}\right]^{+}$at $\mathrm{m} / \mathrm{z} 463,445$ and 427, respectively. As in the 
case of $\alpha$-ecdysone 1, a fragment ion, resulting either from the loss of the $\mathrm{HO}-\mathrm{CH}=\mathrm{CH}$ $\mathrm{CH}_{2}-\mathrm{C}(\mathrm{Me})_{2} \mathrm{OH}(116$ a.m.u. $)$ side chain from the intermediate fragment ion $\left[\mathrm{M}+\mathrm{H}-\mathrm{H}_{2} \mathrm{O}\right]^{+}$ at $\mathrm{m} / \mathrm{z} 463$ or from the loss of the $\mathrm{HO}-\mathrm{CH}=\mathrm{CH}-\mathrm{CH}=\mathrm{C}(\mathrm{Me})_{2}$ (98 a.m.u.) side chain from the intermediate fragment ion $\left[\mathrm{M}+\mathrm{H}-2 \mathrm{H}_{2} \mathrm{O}\right]^{+}$at $\mathrm{m} / \mathrm{z} 445$, was observed at $\mathrm{m} / \mathrm{z} 347$. This fragment ion may lose a molecule of water to afford the fragment ion $\left[\mathrm{M}+\mathrm{H}-2 \mathrm{H}_{2} \mathrm{O}-\right.$ $116]^{+}$at $\mathrm{m} / \mathrm{z} 329$.

$\mathrm{CAD} \mathrm{MS} / \mathrm{MS}$ of the protonated molecular ion $[\mathrm{M}+\mathrm{H}]^{+}$at $\mathrm{m} / \mathrm{z} 481$, afforded a series of product ions at $\mathrm{m} / \mathrm{z} 463,445,427$, and 371 , as shown in Figure 8 . The proposed fragmentation route of the protonated molecule $[\mathrm{M}+\mathrm{H}]^{+}$of $\beta$-ecdysone 2 , as determined by ESMS and CAD MS/MS, is shown in Figure 9. As in the case of 1, the formation of the fragment ion $\left[\mathrm{M}+\mathrm{H}-2 \mathrm{H}_{2} \mathrm{O}\right]^{+}$at $\mathrm{m} / \mathrm{z} 445$, may originate either by the concerted losses of two molecules of water from the protonated molecular ion $[\mathrm{M}+\mathrm{H}]^{+}$or by a two-step process involving the loss of a molecule of water from the intermediate fragment ion $\left[\mathrm{M}+\mathrm{H}-\mathrm{H}_{2} \mathrm{O}\right]^{+}$ at $\mathrm{m} / \mathrm{z} 463$. The product fragment ion at $\mathrm{m} / \mathrm{z} 371$, has been assigned as $\left[\mathrm{M}+\mathrm{H}-3 \mathrm{H}_{2} \mathrm{O}\right.$ $\left.\mathrm{CH}_{2}=\mathrm{C}(\mathrm{Me})_{2}\right]^{+}$and originated from the loss of the $\mathrm{CH}_{2}=\mathrm{C}(\mathrm{Me})_{2}$ (56 a.m.u.) side chain from the $\left[\mathrm{M}+\mathrm{H}-3 \mathrm{H}_{2} \mathrm{O}\right]^{+}$product ion at $\mathrm{m} / \mathrm{z} 427$.

The ESMS of $\beta$-ecdysone 2 , in the negative ion mode, afforded only a major peak at $\mathrm{m} / \mathrm{z} 515$, which was assigned to the molecular deprotonated adduct with two molecules of water, namely $\left[\mathrm{M}-\mathrm{H}+2 \mathrm{H}_{2} \mathrm{O}\right]^{-}$.

Preliminary investigation on hemolymph obtained from snow crabs seems to indicate the presence of these two moulting hormones in small amounts [22].

\section{Experimental}

2,3,14,22,25-pentahydroxycholest-7-en-6-one ( $\alpha$-ecdysone) and 2,3,14,20,22,25-hexahydroxycholest-7-en-6-one ( $\beta$-ecdysone) were purchased from Sigma Chemical Company, St. Louis, Missouri, U.S.A.

HPLC separation of a mixture of $\alpha$ - and $\beta$-ecdysone $(1: 1,0.27 \mathrm{mg} / \mathrm{ml})$ was performed, using a Hewlett Packard 10 HPLC system, fitted with a VYDAC 218 TP52 column (no guard column) eluted with a solvent gradient of $40-100 \%$ acetonitrile in water containing $0.17 \%$ of trifluoroacetic acid. Analysis time was 25 minutes (Rt. $=11.9$ for $\beta$ ecdysone and Rt. $=14.6$ for $\alpha$-ecdysone).

ESMS was performed either by direct injection into the electrospray source through the Rheodyne injector with a $20 \mu \mathrm{l}$ loop or through the Hewlett Packard 10 HPLC system containing the VYDAC column. Obviously the ESMS spectra were identical in each case.

The ESMS (positive and negative ion modes) were measured with a Fisons VGQuattro quadrupole-hexapole-quadrupole mass spectrometer, equipped with an electrospray ionization source, capable of analyzing ions up to $\mathrm{m} / \mathrm{z} 4000$. A $486,66 \mathrm{MHz}$ personal computer equipped with Fisons MASSLYNX Mass Spectrometer Data System Software, was used for data acquisition and processing.

The temperature of the ES ionization source was maintained at $70^{\circ} \mathrm{C}$. The voltage of the ES capillary was $3.4 \mathrm{KV}$ and the $\mathrm{HV}$ lens was at $0.4 \mathrm{KV}$ throughout the whole operation. ESMS were recorded with a focus setting varying from 30 to 75 volts. Generally, higher voltage induced fragmentation of lower molecular weight samples. Conventional ESMS were obtained by scanning in the Multichannel Analysis mode (MCA) with a scan dwell time of 1s/250 a.m.u.. Spectra are an average of 3-4 scans. The mass scale was calibrated using a polyethylene glycol mixture (PEG 300/600/1000) in the positive ion mode and a sugar mixture (corn syrup, raffinose, maltose and maltotetraose) in the negative 


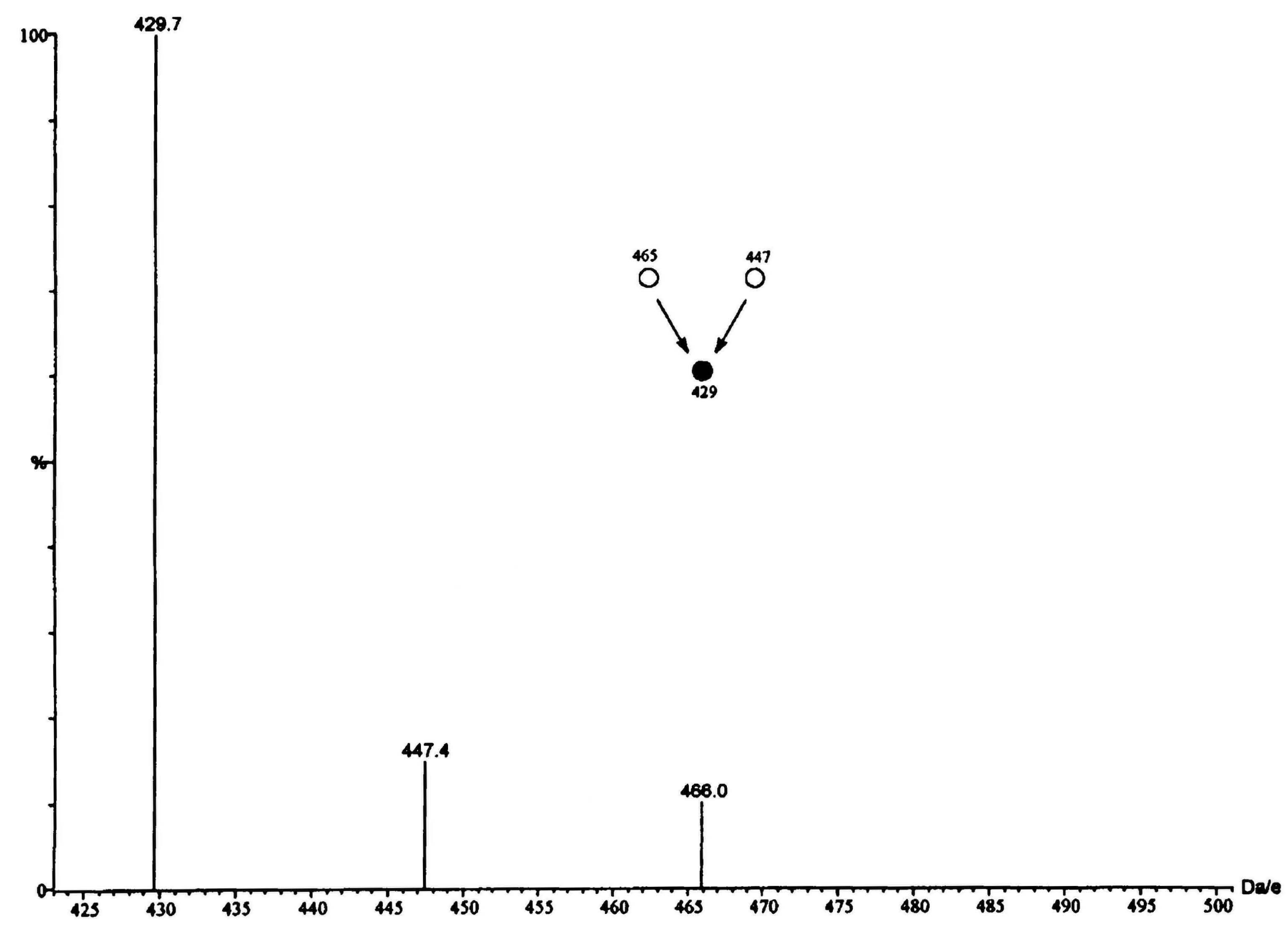

Figure 5. Precursor ion scan of the fragment ion $\left[\mathrm{M}+\mathrm{H}-2 \mathrm{H}_{2} \mathrm{O}\right]^{+}$at $\mathrm{m} / \mathrm{z} 427$ from $\alpha$-ecdysone 1 .

Figure 6. Precursor ion scan of the fragment ion $\left[\mathrm{M}+\mathrm{H}-2 \mathrm{H}_{2} \mathrm{O}-\mathrm{C} 6 \mathrm{H}_{10} \mathrm{O}\right]^{+}$at $\mathrm{m} / \mathrm{z} 331$ from $\alpha$-ecdysone 1.

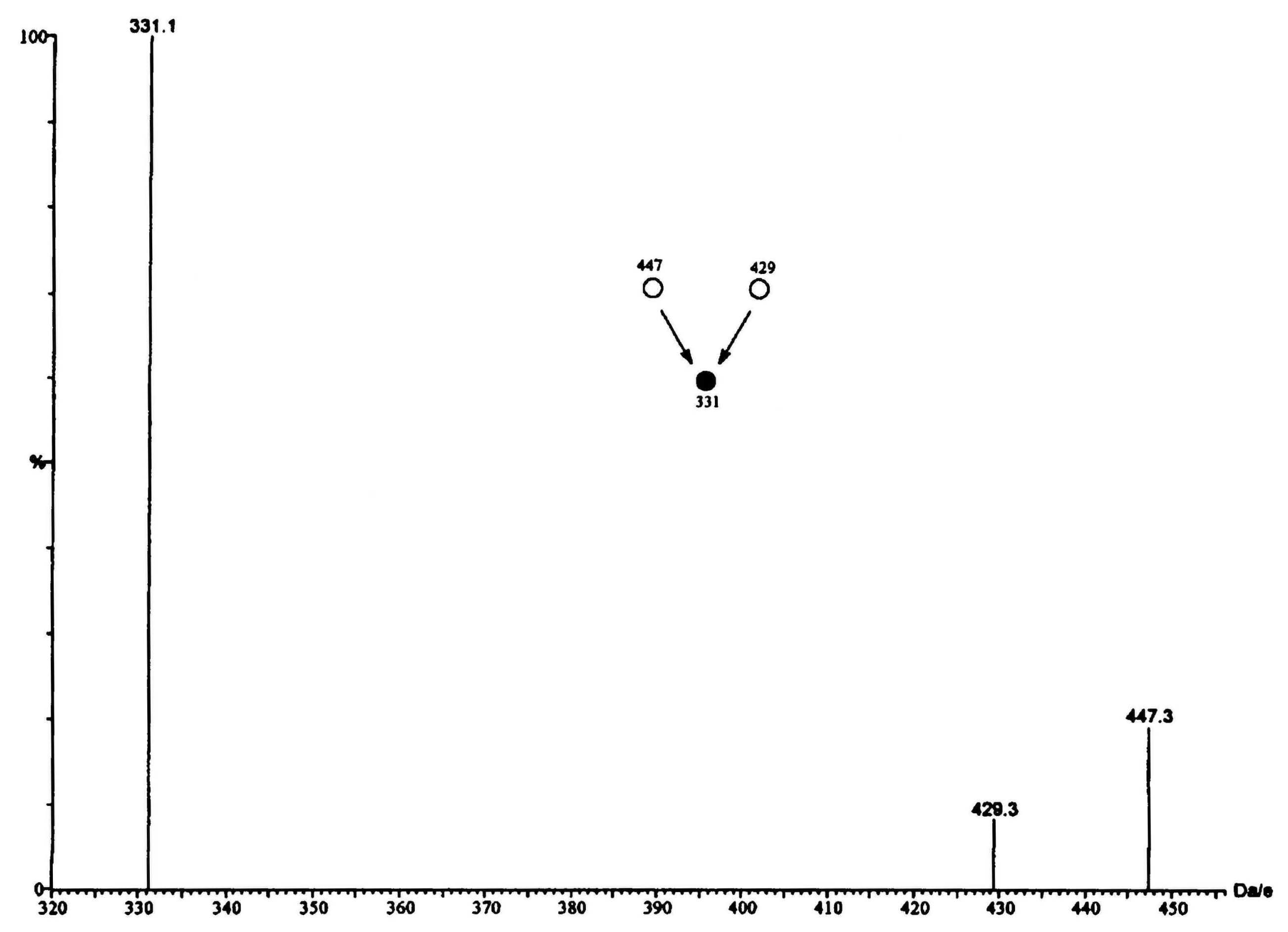



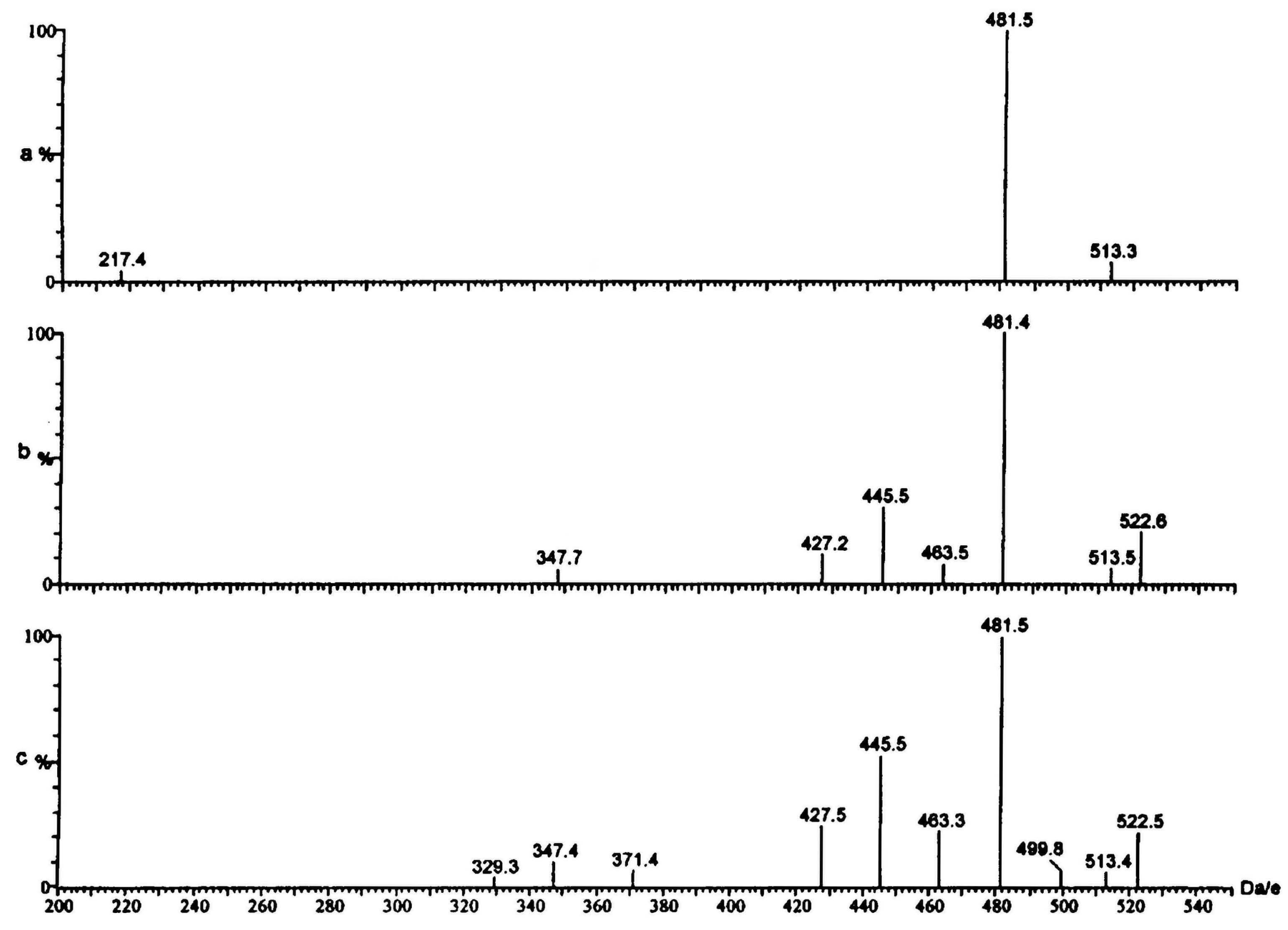

Figure 7. Electrospray mass spectra of $\beta$-ecdysone 2 recorded with focus voltages of (a) 30 Volts, (b) 50 Volts and (c) 75 Volts.

Figure 8. Low energy CAD MS/MS of the molecular ion $[\mathrm{M}+\mathrm{H}]^{+}$of $\beta$-ecdysone 2 at $\mathrm{m} / \mathrm{z} 481$.

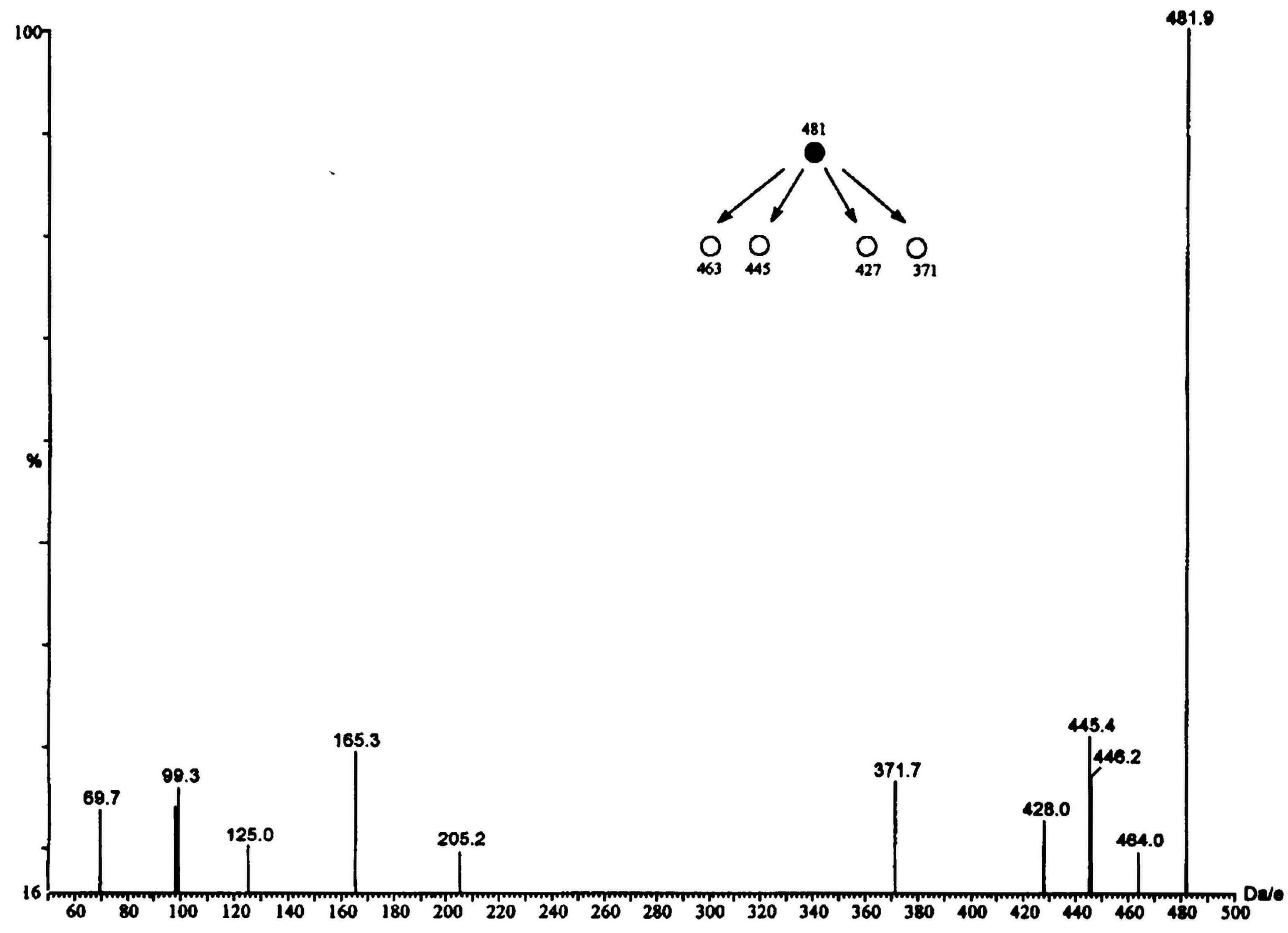


<smiles>CC(C)(O)CCC(O)[C@](C)(O)[C@H]1CCC2(C)C3CCC4(C)C(=CC(=O)C5CC(O)C(O)CC54C)C3CCC12C</smiles>

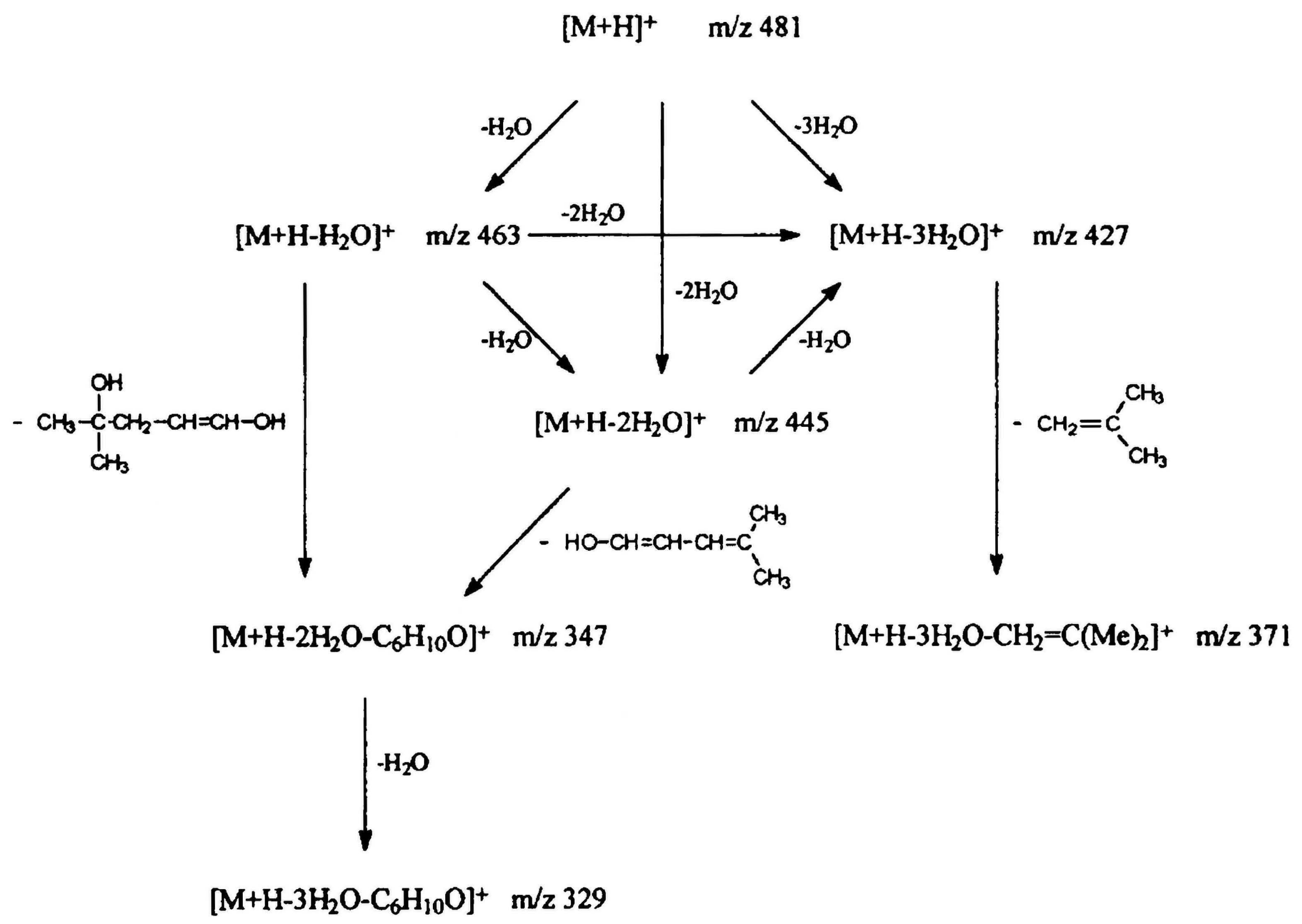

Figure 9. Major fragmentation routes of the $[\mathrm{M}+\mathrm{H}]^{+}$ion of $\beta$-ecdysone 2 observed by ESMS and CAD MS/MS.

ion mode. MS/MS experiments were conducted on the same instrument. Fragment ion spectra of mass-selected ions were induced by collision with argon in the second (RFonly) hexapole. Argon collision gas was added in the enclosed chamber of the hexapole to give a pressure of $2 \times 10^{-5} \mathrm{mBar}$, for collisional activation of the sample ions. The resulting fragments were analyzed by the second quadrupole. Collision energies of approximately 50 $\mathrm{eV}$ were used in all MS/MS experiments. 


\section{Conclusion}

Mass spectral analyses of ecdysones have been facilitated using electrospray ionization. Abundant signals, corresponding to the protonated molecules, were observed in each case, using this ionization technique. Collision induced dissociations in the atmospheric pressure/vacuum interface were promoted by increasing the accelerating voltages and have provided additional structural information. MS/MS spectra of the moulting hormones, obtained using low energy collisional activation, permitted the rationalization of the fragmentation pathways. Furthermore, daughter and parent ion series and MS/MS spectra of selected intermediate ions, formed during the cone voltage fragmentation of the ionized species, permitted rationalization of the fragmentation behaviour.

\section{References}

[1] E. S. Chang and J. D. O'Connor, in H. Laufer and R. G. H. Downer (Editors), Endocrinology of Selected Invertebrate Types, Alan R. Liss Inc., New York, p. 259 (1988).

[2] J. P. Delbecque, K. Weidner, and K. H. Hoffman, Invert. Reprod. Devel., 18 (1990) 29.

[3] H. H. Rees, in J. Koolman (Editor), Radioimminoassay of Ecdysteroids, Georg Thieme Verlag, Stuttgart, p. 152 (1989).

[4] J. T. Warren and C. Hetru, Invert. Reprod. Devel., 18 (1990) 91.

[5] E. D. Morgan and C. F. Poole, Org. Mass Spectrom., 9 (1974) 333.

[6] N. Ikekawa, F. Hattori, J. Rubio-Lightbourn, H. Miyazaki, M. Ishibashi, and L. Mori, J. Chromat.Sci., 10 (1972) 233.

[7] D.W. Borst and J.D. O'Connor, Steroids, 24 (1974) 637.

[8] L. Dinan, J. Steroid Biochem, 31 (1988) 237.

[9] I.D. Wilson, R. Lafont, and P. Wall, J. Plan. Chromat., 1 (1988) 357.

[10] F. Lachaise, G. Carpentier, G. Somme, J. Colardeau, and P. Beydon, J. Exp. Zool., 252 (1989) 283.

[11] P.H. Rudolph, E. Spaziani, and W.C. Wang, Gen. Comp. Endocrinol., 88 (1992) 224.

[12] M.P. Marco, F.J. Sanchez-Baeza, F. Camps, and J. Coll, J. Chromat., 441 (1993) 81.

[13] E. D. Morgan and M. P. Marco, Invert. Reprod. Develop., 18 (1990) 55.

[14] A. L. Burlingame, R. K. Boyd, and S. J. Gaskell, Mass Spectrom. Anal. Chem., 66 (1994) 634R.

[15] T. R. Covey, R. F. Bonner, B. I. Shushan, and J. Henion, Rapid Commun. Mass Spectrom, 2 (1988) 249.

[16] J. A. Loo, H. R. Udseth, and R. D. Smith, Anal. Biochem, 179 (1989) 404.

[17] K. L. Busch, G. L. Glish, and S. A. McLuckey, in Mass Spectrometry/Mass Spectrometry: Techniques and Applications of Tandem Mass Spectrometry, VCH, New York, 1988, p. 333.

[18] F. W. McLafferty, in Tandem Mass Spectrometry, Wiley Interscience, New York, p. 506.

[19] V. M. Wysoki, in M. L. Gross (Editor), Nato ASI Series C: Mathematical and Physical Sciences, Vol. 9, Kluver Academic Publishers, Dordrecht/Boston/London, 1992, p. 59.

[20] A. Kamel Harrato, L. N. Dolmelsmith, and R. B. Cole, Biol. Mass Spectrom., 22 (1993) 59.

[21] J. N. Louris, L. G. Wright, R. D. Cooks, and A. E. Schoen, Anal. Chem., 57 (1985) 2918.

[22] J. Hellou, J. Banoub, E. Gentil, D.Taylor, and P. O'Keefe, unpublished data. 


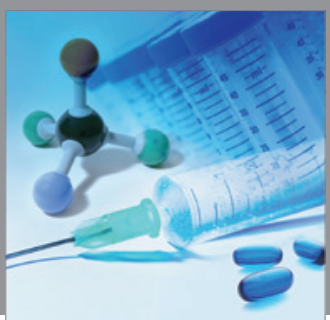

International Journal of

Medicinal Chemistry

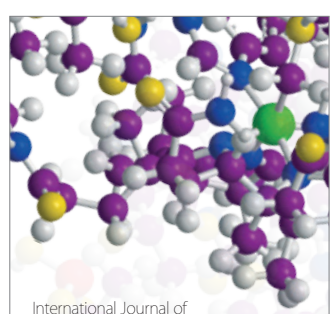

Carbohydrate Chemistry

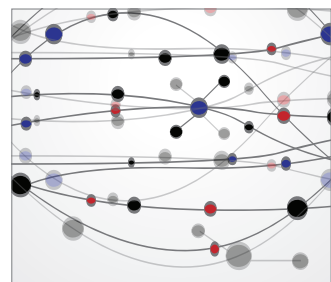

The Scientific World Journal
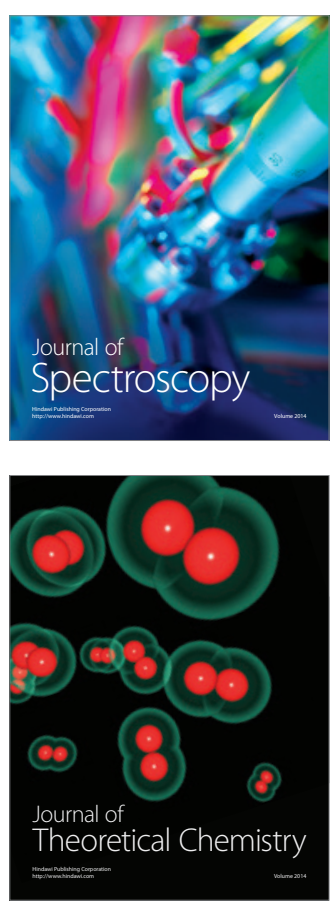
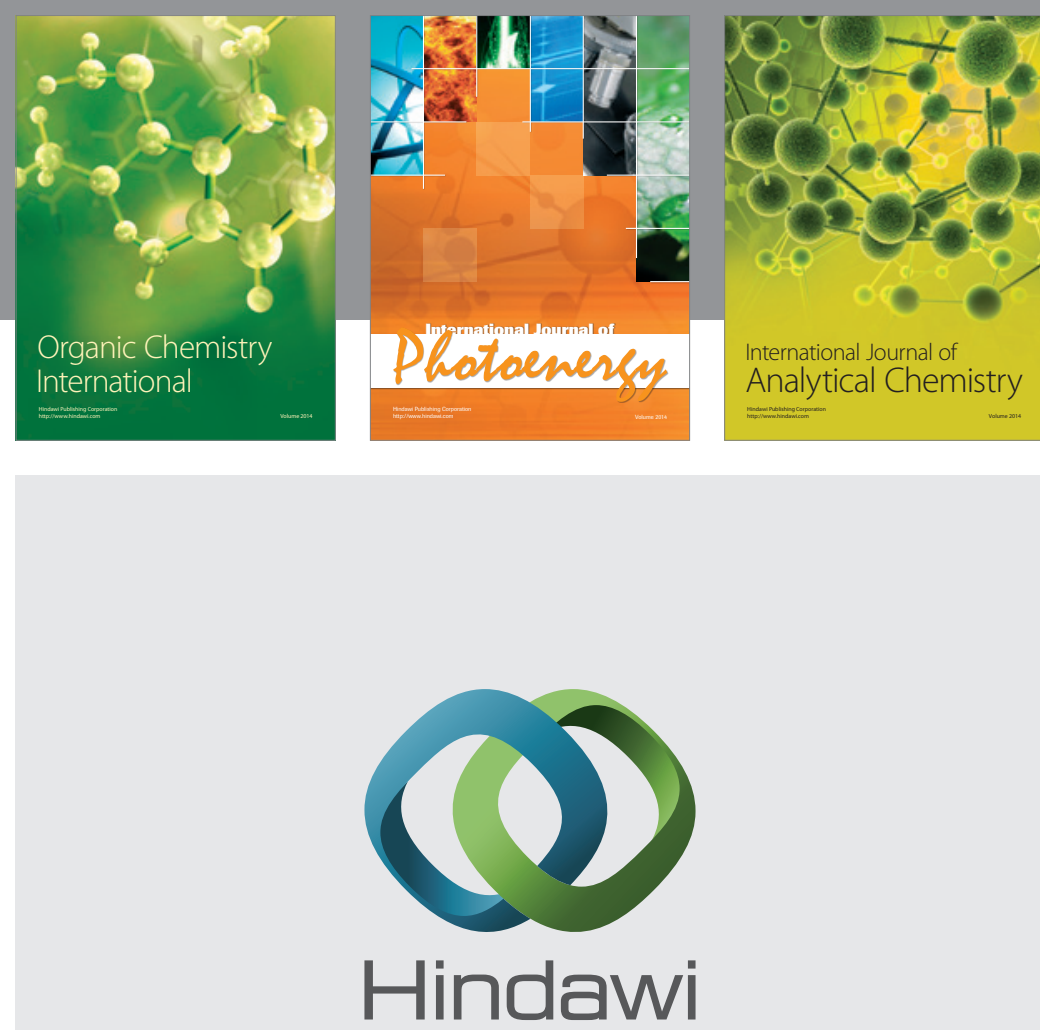

Submit your manuscripts at

http://www.hindawi.com
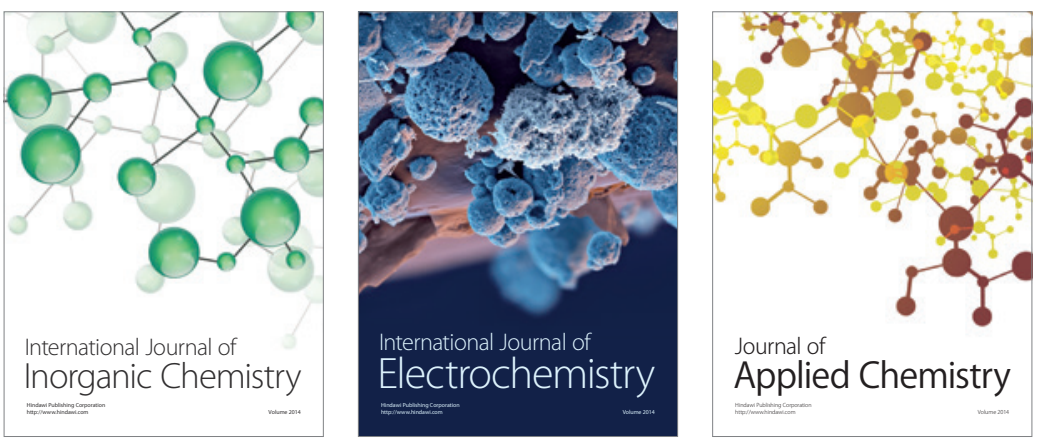

Journal of

Applied Chemistry
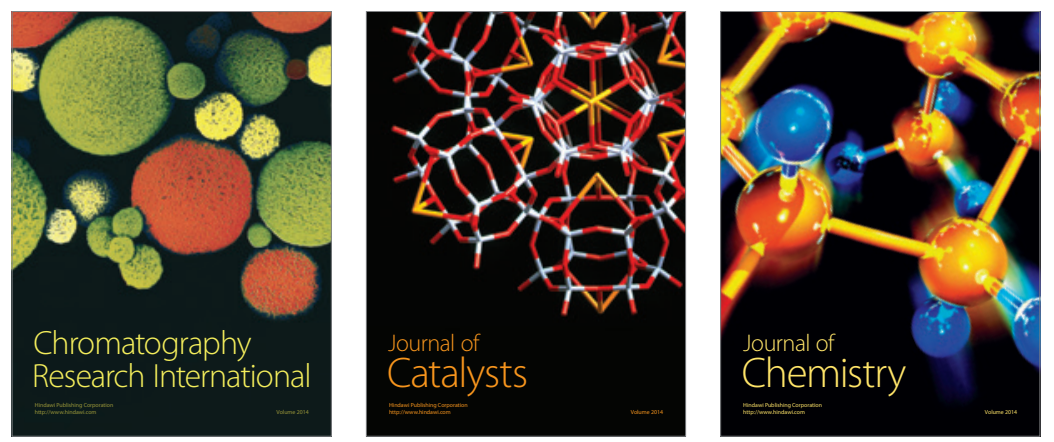
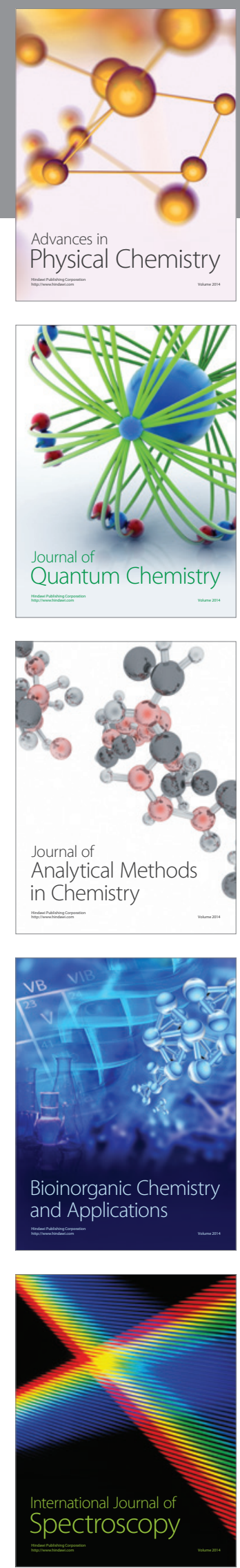